\title{
现代蒙古高原与中纬度东亚季风区夏季降水 一致性变化的空间范围及其成因
}

陈婕 ${ }^{1}$, 黄伟 ${ }^{*}$, Qiong $Z \mathrm{ZHANG}^{2}$, Song $\mathrm{FENG}^{3}$

1. 兰州大学资源环境学院, 西部环境教育部重点实验室, 兰州 730000;

2. Department of physical geography, Bolin Centre for Climate Research, Stockholm University, Stockholm 10691, Sweden;

3. Department of Geosciences, University of Arkansas, Fayetteville 72701, USA

* 通讯作者, E-mail: whuang@1zu.edu.cn

收稿日期：2019-11-03; 收修改稿日期：2020-01-02; 接受日期：2020-02-25; 网络版发表日期：2020-05-11

国家自然科学基金项目(批准号: 41790421, 41877446)和中央高校基本科研业务费专项资金项目(编号: lzujbky-2018-140)资助。

摘要蒙古高原地处亚洲中部干旱区东部, 受到西风环流的主控, 表现出干旱半干旱气候特征, 其东部受到季风 环流的影响, 表现为湿润半湿润气候特征的中纬度东亚季风区. 但有研究关注到该地区现代夏季降水的变化与亚 洲中部干旱区西部变化并不一致, 却与中纬度东亚季风区表现出同相位的降水变化特征. 为了查明这种降水一致 性的空间范围, 文章使用1979 2016年GPCC数据集的逐月降水资料, 分别对蒙古高原夏季降水年际和年代际信号 进行分析. 结果显示: 蒙古高原与中纬度东亚季风区在年际和年代际尺度上都呈现出了基本一致的降水变化特 征, 一致性变化区域主要为蒙古高原、中国东北和华北地区. 进一步对蒙古高原与中纬度东亚季风区年代际出现 降水一致性变化的物理机制进行研究，发现北大西洋和中亚地区与欧洲和蒙古高原高度场异常反相位配置的欧 亚大陆中纬度遥相关波列是导致降水一致性变化的关键因素. 当北大西洋和中亚地区为高度场正异常, 而蒙古高 原出现高度场负异常这种环流配置时, 能够将更多的西风和中纬度季风水汽输送到蒙古高原、中国东北和华北 地区，并且通过加强东北亚低压来增强东亚夏季风，还可以激发异常上升运动，从而导致主要受西风环流控制的 蒙古高原和受季风环流控制的中国东北和华北地区降水出现一致性增加. 反之则出现一致性降水减少. 这项研究 将对理解东亚古降水/湿度重建样点的空间代表性, 以及厘清区域气候的一致性背景具有指示性意义.

关键词 蒙古高原, 中纬度东亚季风区, 夏季降水, 年代际, 一致性变化

\section{1 引言}

蒙古高原地处欧亚大陆腹地, 东起大兴安岭, 西至 阿尔泰山, 地势自西向东逐渐降低, 横跨亚洲中部干旱 区东部，年降水量从西南的少于 $50 \mathrm{~mm}$ 到东北超过了
$350 \mathrm{~mm}$, 以草原植被生态系统为主, 是西伯利亚针叶 林和戈壁沙漠之间的过渡区(Wesche等，2016). 同时， 蒙古高原也是中国北方重要的绿色生态屏障, 以及东 亚沙尘灾害的源区之一(Chung等，2003；Fujiwara等， 2007). 而蒙古高原由于具有干旱半干旱气候特征，降 
水偏少，其降水变化对生态环境、农业生产以及沙尘 暴的发生频率都有强烈的影响(Munkhtsetseg等, 2007; Yamanaka等, 2007; Lee和Sohn, 2011). 因此, 深入理解 蒙古高原降水变化是开展各项气候生态环境研究的基 础，对加强中国生态安全和风险防范等方面也都具有 重要理论与现实意义.

蒙古高原降水集中在夏季(6 8月), 水汽主要来源 于西风的传输(Piao等, 2018), 尽管西风和东亚夏季风 的相互作用可以影响到蒙古高原东部地区(Chen等, 2008, 2019; 陈婕等, 2018), 但夏季风却很难深入到蒙 古高原核心地区(Sato等, 2007). 在中全新世时期, 东亚 夏季风较现在更为强盛, 有研究结果显示季风可以影 响到蒙古高原的降水(Gunin等, 1999; An等, 2008), 但 是季风能推进到哪里还存在争议(An，2000; Chen等, 2008; Wang和Feng, 2013). Li等(2009)基于过去400年 树轮数据重建的亚洲地区帕尔默干旱指数(PDSI)发 现, 蒙古高原的湿度与华北地区出现一致的变化趋势. 基于现代器测资料的研究也发现，20世纪90年代末以 来, 东亚夏季风减弱直接导致华北降水减少 (Zhu等, 2011, 2016; Huang等, 2013; Zuo等, 2013; Xu等, 2015; Liu等, 2017), 同期蒙古高原降水也出现了显著的减少 (Piao等，2017)。黄伟等(2015)对近几十年中纬度欧亚 大陆的夏季降水进行EOF分析，发现蒙古高原和华北 在年际和年代际尺度上的降水变化趋势基本一致. 可 见，尽管主要受到西风环流控制的蒙古高原是干旱半 干旱气候，但是该地区的降水却与受季风环流控制的 华北地区可能存在一致的变化特征.

然而，受不同大气环流主控、位于干旱半干旱区 的蒙古高原为何与湿润半湿润区的华北出现一致的降 水变化特征? 尽管已经有研究注意到了这个现象, 但 是并没有对此进行深入地研究. 此外, 该降水一致性 的空间范围尚不确定，造成这种现象的原因也不清楚. 为此, 本文拟从现代降水数据集和大气环流资料入手, 探讨1979 2016年蒙古高原夏季降水变化一致性的空 间范围及原因. 这不仅对更深入地理解蒙古高原降水 变化机制以及亚洲降水空间格局有重要意义，也可为 古气候重建研究提供明晰的区域气候背景.

\section{2 资料和方法}

研究使用了 4 套月分辨率降水数据集, 包括
1901 2016年全球降水气候学中心(Global Precipitation Climatology Centre; GPCC) 空间分辨率为 $1.0^{\circ} \times 1.0^{\circ}$ 的 全球陆地逐月格点降水数据集(Schneider等，2018); 1979 2016年全球气候学降水(Global Precipitation Climatology Project; GPCP)数据集, 空间分辨率为 $2.5^{\circ} \times 2.5^{\circ}$ (Huffman等, 2009$)$; 英国东英吉利大学气候 研究中心(Climatic Research Unit; CRU)建立的空间分 辨率为 $0.5^{\circ} \times 0.5^{\circ}$ 的格点降水数据集 $(\mathrm{TS} 4.02 ;$ Harris等, 2014); 以及美国Delaware大学建立的空间分辨率为 $0.5^{\circ} \times 0.5^{\circ}$ 全球格点降水数据集(V5.01; http://climate. geog.udel.edu/ climate/html_pages/Global2017/ README.GlobalTsP2017.html). 风场、高度场和垂直 速度等大气环流数据来自欧洲中期天气预报中心 (European Centre for Medium-Range Weather Forecasts, $\mathrm{ECMWF}$ )提供的逐月ERA-Interim数据集，空间分辨率 为 $2.5^{\circ} \times 2.5^{\circ}$ (Dee等, 2011).

整层垂直水汽通量季风计算公式为

$\boldsymbol{Q}=\frac{1}{\mathrm{~g}} \int_{300 \mathrm{hPa}}^{P_{s}} q \boldsymbol{V} \mathrm{d} p$

式中, $\boldsymbol{Q} 、 \mathrm{~g} 、 q 、 \boldsymbol{V}$ 和 $P_{s}$ 分别代表水汽通量、重力加速 度、比湿、风场和地表气压，并在计算时考虑了地形 的影响. 为了进一步研究低层和中高层水汽的影响, 分别对低层 $(1000 \sim 700 \mathrm{hPa})$ 和中高层 $(700 \sim 300 \mathrm{hPa})$ 水汽 通量进行积分. 此外, 本文还使用了Lanczos低通和高 通滤波方法获取数据的年际和年代际信号(Duchon, 1979), 滤波窗口均为9年.

\section{3 结果}

\section{1 蒙古高原降水变化一致性空间范围探讨}

为了探讨蒙古高原夏季降水在多大空间范围存在 变化一致性, 首先需要了解蒙古高原夏季降水的时空 变化特征. 将蒙古高原主体 $\left(42^{\circ} \mathrm{N} \sim 52^{\circ} \mathrm{N}, 92^{\circ} \mathrm{E} \sim 116^{\circ} \mathrm{E}\right)$ 的夏季(6 8月)降水进行滤波处理，分解成年际和年代 际信号, 之后再进行区域平均并标准化, 得到了该地区 年际和年代际夏季标准化降水时间序列(图 $1 \mathrm{a}$ 和 $1 \mathrm{~b}$ ). 结果显示, 蒙古高原夏季年际降水的波动幅度较大, 波 动幅度在20世纪90年代末出现了减弱(图1a), 而年代 际降水自 20 世纪90年代末以来也出现了减弱(图1b).

进一步将蒙古高原标准化降水时间序列与亚洲中 

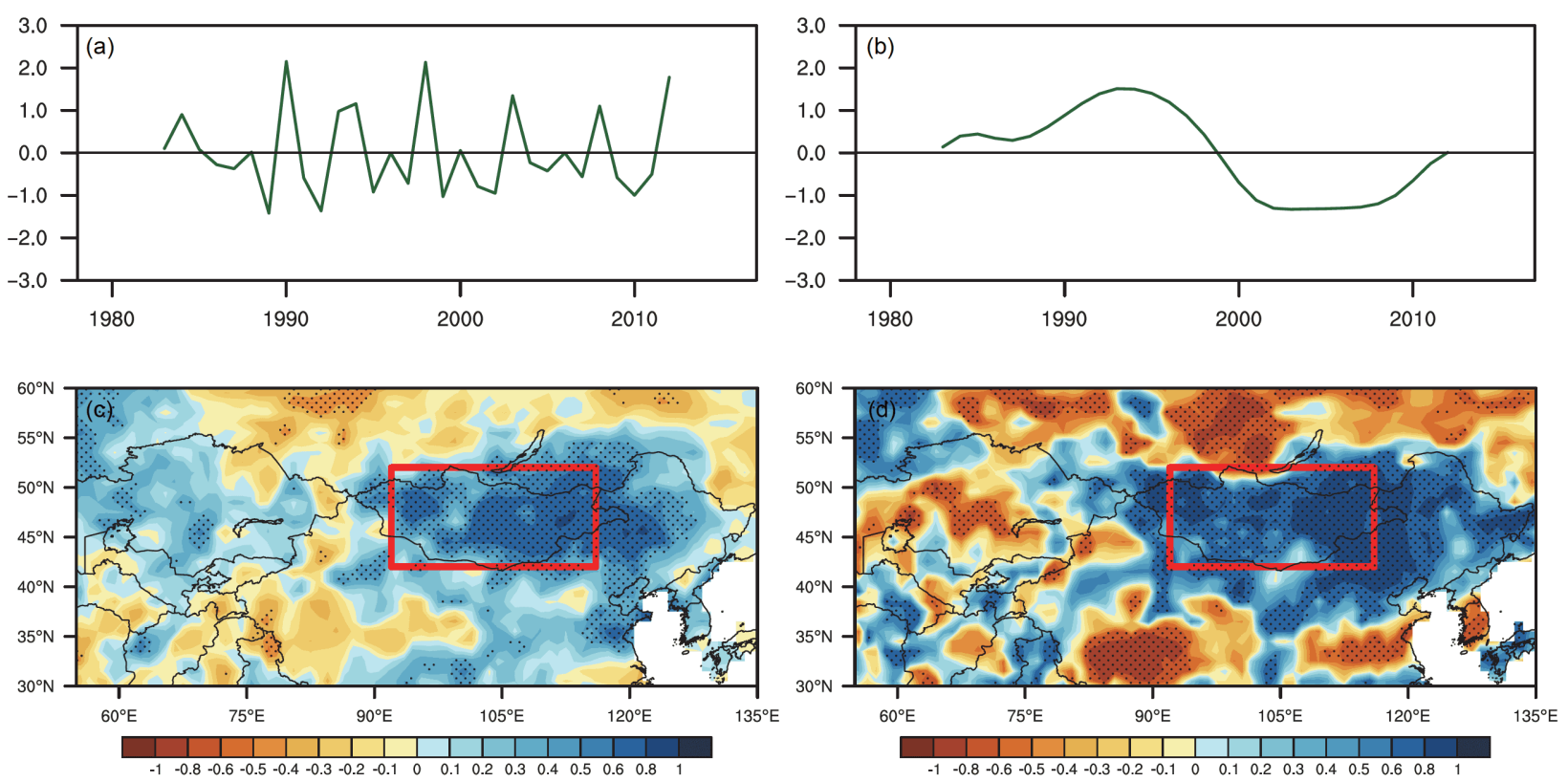

图 1 1979 2016年蒙古高原年际(a)、年代际(b)尺度标准化夏季降水时间序列以及年际(c)、年代际(d)蒙古高原区域夏季平 均降水与亚洲中纬度降水的相关

红色长方形区域为本文所取蒙古高原主体范围, 黑色圆点代表相关系数通过了 $95 \%$ 的蒙特卡洛显著性检验

纬度地区 $\left(30^{\circ} \mathrm{N} \sim 60^{\circ} \mathrm{N}, 55^{\circ} \mathrm{E} \sim 135^{\circ} \mathrm{E}\right)$ 的降水进行空间相 关分析. 结果发现, 在夏季年际尺度上, 蒙古高原各地 区与区域平均降水呈现出显著的正相关关系，表明蒙 古高原地区整体降水变化具有一致性. 此外, 显著的正 相关关系还出现在了中国东北西部地区以及华北地区, 正相关中心位于蒙古高原中东部和中国东北西部地区, 其相关系数超过了 0.6 , 说明这些地区的年际降水变化 特征与蒙古高原基本一致(图1c). 在夏季年代际尺度 上，蒙古高原降水同样呈现出了整体基本一致的变化 特征, 其一致性空间范围也与年际尺度相似: 显著的正 相关关系出现在了整个蒙古高原、中国东北以及华北 地区, 正相关中心主要位于蒙古高原东部和中国东北 西部地区, 其相关系数超过了 0.8 ; 除了显著的正相关 关系外, 黄淮和江淮地区、青藏高原南部、中亚以及 西伯利亚地区与蒙古高原的夏季降水都呈现出显著的 反相关关系(图1d). 而其中中亚与中纬度东亚季风区的 夏季降水年代际反相关关系是“西风模态”的年代际尺 度表现(黄伟等, 2015), 与前人基本一致的结果也验证 了我们结果的可靠性. 由上所述, 蒙古高原与中纬度东 亚季风区在年际和年代际尺度上都呈现出了基本一致 的夏季降水变化特征. 然而, 对于长时间尺度的古气候
研究来说, 年代际尺度的变化更具有参考价值, 为此, 本文主要关注蒙古高原的年代际降水变化特征.

为了进一步确认蒙古高原与中纬度东亚季风区降 水之间的关系，我们同时使用了GPCC、Delaware、 GPCP和CRU四套降水数据集对年代际夏季降水相关 性进行对比分析, 四套降水数据集都显示出大体一致 的空间相关特征, 即蒙古高原、中国东北和华北地区 呈显著的正相关关系，而与周围地区呈现出显著的负 相关关系(图2a 2d). 只有Delaware数据在蒙古高原中 部部分地区的结果与其他数据集有差别, 显示为负相 关关系, 与蒙古高原主体的降水变化特征相反(图2b), 对比其他数据集发现, GPCC、GPCP和CRU数据在蒙 古高原中部该地区都表现为弱相关中心(图2a, 2c 和 2d), 说明这个地区与蒙古高原其他地区的降水联系较 弱, Delaware与其他数据集在此地的差别很可能是由 数据误差导致, 而非真实情况. 4套数据集所表现出的 大体一致的空间相关性验证了年代际尺度上蒙古高原 与中纬度东亚季风区的夏季降水一致性空间变化模态 是客观存在的.

事实上, 使用1979 2016年数据进行年代际变化研 究年限相对较短, 为此我们还对1901 2016年降水进行 
(a) GPCC

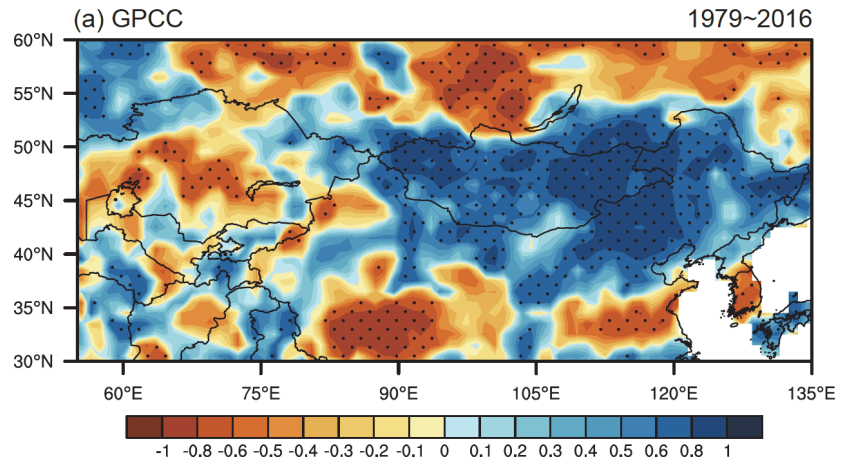

(c) GPCP

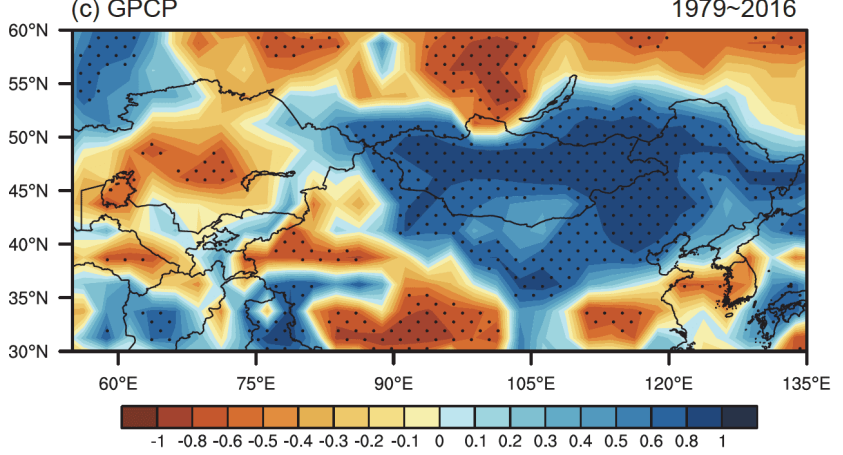

(b) Delaware

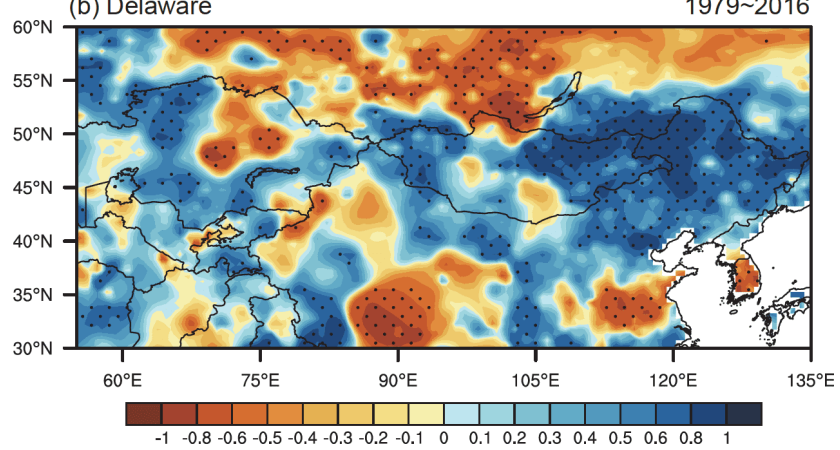

(d) CRU

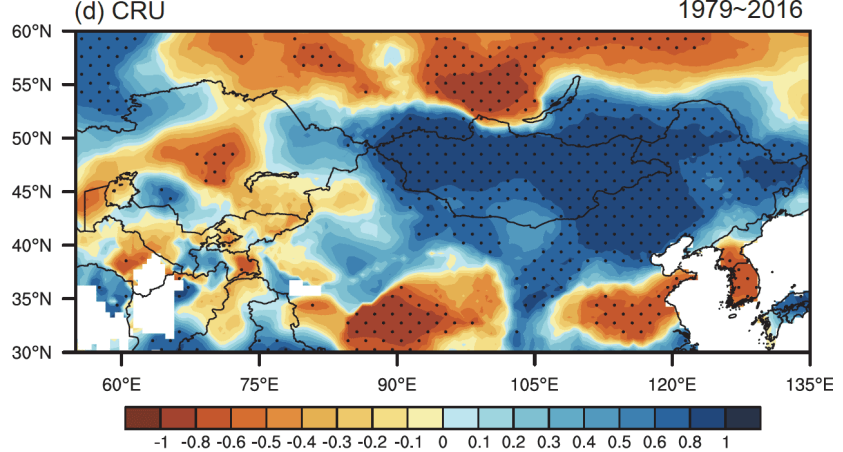

(e) GPCC

$1901 \sim 2016$

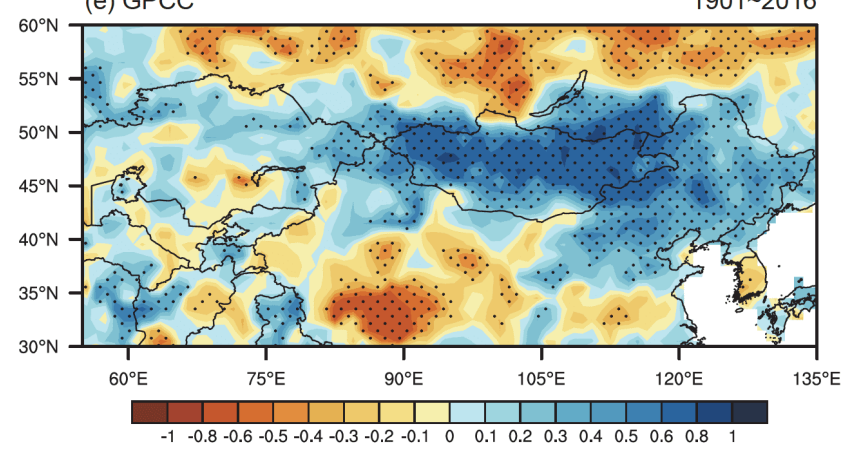

图 2 1979 2016年GPCC(a)、Delaware(b)、GPCP(c)和CRU(d), 以及1901 2016年GPCC(e) 降水数据集在年代际尺度上蒙 古高原区域平均夏季降水与亚洲中纬度降水的相关分析

黑色圆点代表相关系数通过了 $95 \%$ 的蒙特卡洛显著性检验

了年代际的相关分析，结果发现蒙古高原、中国东北 和华北的降水依然呈显著的正相关关系(图2e)，表明 降水一致性变化特征在过去百年依然存在. 基于此, 我们进一步对这种降水一致性变化模态的机制进行探 讨. 由于 20 世纪初东亚的观测资料稀少, 环流资料基本 为空白, 与过去百余年相比, 过去近 40 年的再分析资料 更加接近真实情况，并且过去近 40 年的降水变化结果 与过去百余年基本一致，说明过去百年这种降水模态 相对稳定，因此本文使用1979 2016年的资料进行环 流分析.
3.2 蒙古高原与中纬度东亚季风区降水一致性变 化物理机制

气候态时, 蒙古高原的夏季降水主要受来自中国 西北方向的西风水汽输送的影响; 对于中国东北和华 北地区，除了受西风水汽影响外，同时也受到亚洲夏 季风水汽影响(图3a). 为了进一步研究蒙古高原异常 降水的水汽来源, 我们将蒙古高原区域平均降水与整 层水汽通量进行合成分析和回归分析. 可以发现, 合 成分析与回归分析的结果基本一致, 在蒙古高原地区 
存在一个异常气旋，该气旋覆盖了整个蒙古高原、中 国东北和华北，中心位于蒙古高原中东部，使得蒙古 高原和中纬度东亚季风区出现异常水汽辐合; 而中亚 存在一个异常反气旋, 使得水汽辐散; 异常西风水汽 通过中亚的异常反气旋输送至蒙古高原南部地区，并 经由蒙古高原的异常气旋进一步输送到华北、中国东 北和蒙古高原北部地区; 此外, 在中国东南部地区出现 了一个异常反气旋，季风水汽可以通过这个反气旋输 送到华北地区，然后经由异常气旋输送至东北地区， 并且可能进一步输送到蒙古高原(图3b和3c).

为了更深入地理解蒙古高原异常降水的水汽来 源，我们进一步将水汽分为低层和中高层水汽进行回 归分析. 结果显示, 在低层和中高层, 中国东南部地区 都出现了异常反气旋. 然而可以注意到, 低纬的水汽主 要由低层的异常反气旋输送至中纬度, 而东亚夏季风 属于低层环流系统，说明在蒙古高原降水增多时，确 实有更多的低纬季风水汽被输送至中纬度地区. 此外, 在蒙古高原的低层和中高层都存在异常气旋，除了低
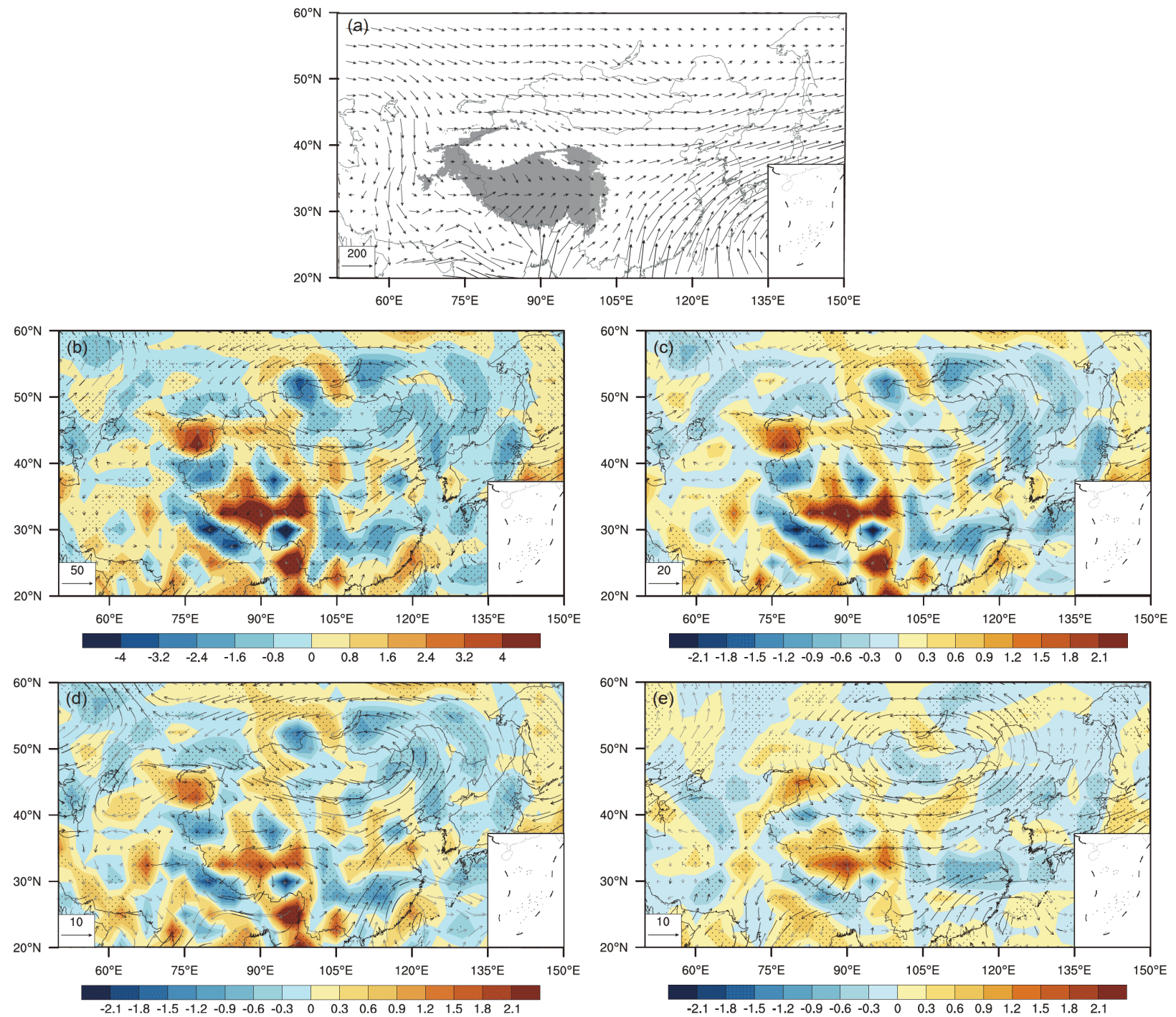

图 3 气候态整层水汽通量(a)、蒙古高原区域平均夏季降水高值年代(1983 1999年)减去低值年代(2000 2012年)对应的整 层水汽通量/水汽通量散度(b)的合成分析, 以及蒙古高原区域平均夏季降水与整层 $(c)$ 、低层(d)和中高层(e)水汽通量/水汽通 量散度的回归分析

水汽通量单位为 $\mathrm{kg} \mathrm{m}^{-1} \mathrm{~s}^{-1}$, 水汽通量散度单位为 $\mathrm{m} \mathrm{s}^{-1} \mathrm{~kg} \mathrm{~kg}^{-1}$, 图中水汽通量散度结果乘以了 $10^{5}$, 黑色箭头和黑色圆点代表结果通过了 $90 \%$ 的 显著性检验, (a)中灰色区域代表海拔高度超过 $3000 \mathrm{~m}$ 
层的异常气旋中心主要集中在蒙古高原东部地区、较 高层气旋中心范围偏小、异常水汽辐合位置稍有差别 外，两者的强度和范围基本一致，为准正压结构; 而来 自中亚的异常水汽主要靠低层西风的传输(图3d和3e). 由此可见，蒙古高原、中国东北和华北地区受到同一 个异常气旋控制，该异常气旋可以将更多的西风水汽 和到达中纬度的东亚夏季风水汽输送到蒙古高原、中 国东北和华北地区，为这些地区降水的同时增多提供 必要的水汽条件.

进一步对大尺度大气环流进行分析后发现，在 $200 \mathrm{hPa}$ 上，欧亚大陆中纬度存在一个遥相关波列，当 蒙古高原降水增加时，该波列表现为北大西洋和中亚 地区上空为高度场正异常，欧洲和蒙古高原上空为高 度场负异常(图4a). 从图4b中可以看到, 欧洲、中亚和
蒙古高原上空的高度场异常为正压结构, 异常中心出 现在 $200 \mathrm{hPa}$ 附近. 然而, 在北大西洋地区，高度场异常 中心却出现在了近地面，高度场正异常随着高度增加 而逐渐减弱，并在对流层高层消失(图4b). 事实上， Piao等(2017)发现在蒙古高原降水发生年代际转变的 时候, 欧亚大陆会出现一个遥相关波列, 该遥相关波列 主要受到北大西洋的海温异常的激发. Piao等(2017)发 现的遥相关波列与本文的基本一致. 因此, 我们认为北 大西洋海温异常可以激发该欧亚大陆的遥相关波列, 从而导致蒙古高原上空出现高度场负异常. 此外, 在中 亚和蒙古高原上空分别出现的高度场正异常和高度场 负异常(图4)，导致中亚和蒙古高原出现异常反气旋和 气旋, 将更多的西风和季风水汽输送至蒙古高原、中 国东北和华北地区(图3).
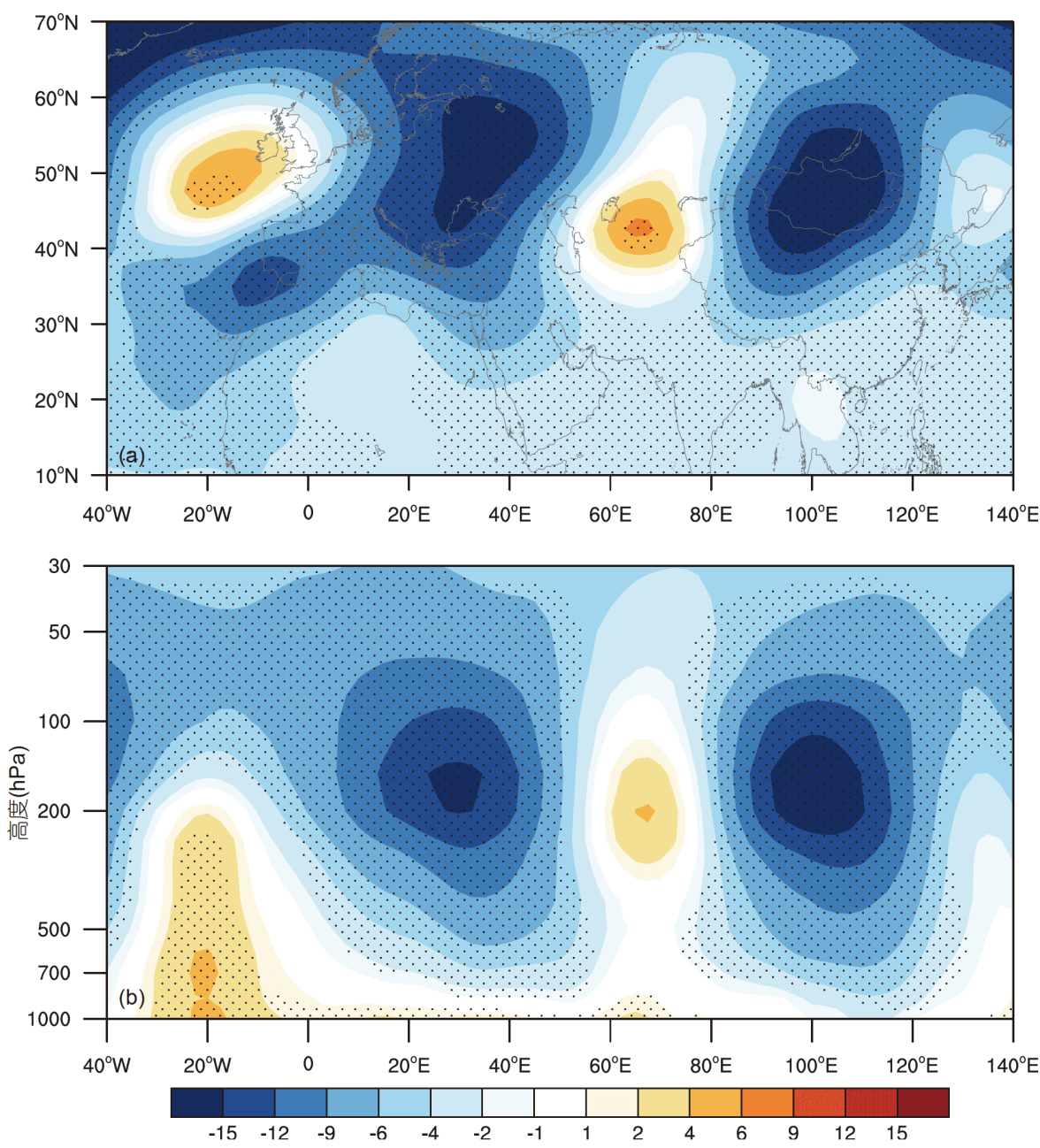

图 4 蒙古高原区域平均夏季降水与 $200 \mathrm{hPa}(\mathrm{a})$ 和高度-经度方向(b)高度场的回归分析 高度场单位为 $\mathrm{m}$, 黑色圆点代表回归分析通过了 $90 \%$ 的显著性检验 
由以上分析可以发现，在蒙古高原与中纬度东亚 季风区降水一致性变化过程中, 除了西风水汽以外, 东 亚夏季风的水汽输送也是其中重要的一环: 当蒙古高 原降水增多时, 中国东南部同时出现一个异常反气旋, 将季风水汽输送到华北地区, 并通过蒙古高原上空的 异常气旋, 将水汽输进一步送到蒙古高原. 然而, 当蒙 古高原降水增多时, 低纬的东亚夏季风为何会增强使 得输送到华北地区的水汽增多? 对于东亚夏季风, 其 强度受位于海洋上的西北太平洋副热带高压和位于陆 地上的东亚低压这两个大尺度环流的影响(郭其蕴, 1983; Han和Wang, 2007; Cheng等, 2008), 其中东亚低压 的中心位于东亚北部地区, 被称为“东北亚低压”(Lin和 Wang, 2016). 从图5a中可以看出, 在 $850 \mathrm{hPa}$ 上, 蒙古高 原上空的高度场负异常中心与东北亚低压的位置基本 吻合, 说明蒙古高原上空出现的高度场负异常可以使 东北亚低压加深. 加深的东北亚低压可以增大它与西 太平洋副热带高压之间的经向位势高度梯度, 从而加 强季风前端的地转西风(陈际龙和黄荣辉, 2007; Lin和 Wang, 2016), 使得中国东南部地区出现异常反气旋, 进 而将更多的季风水汽输送至华北(图5b). 因此, 蒙古高 原上空的高度场负异常不仅可以增强西风, 同时还可 以增强低纬的东亚夏季风, 使得输送到华北的季风水 汽增多, 并且异常西风和季风水汽可以通过蒙古高原

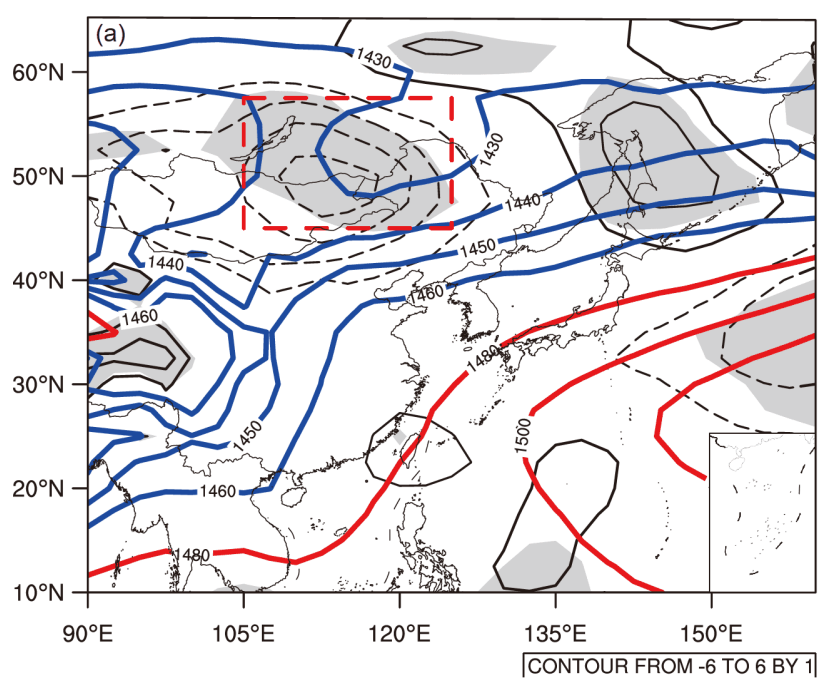

上空的气旋进一步输送到东北和蒙古高原，为蒙古高 原和中纬度东亚季风区的降水提供水汽支持.

然而, 我们可以注意到, 蒙古高原降水与东亚夏季 风是通过蒙古高原上空的高度场负异常联系起来的. 为了进一步厘清它们之间的关系, 我们计算了年代际 蒙古高原降水、东亚夏季风指数和东北亚低压指数之 间的相关关系. 蒙古高原降水与东北亚高度场异常指 数的相关系数为 0.55 ; 东北亚低压指数与使用经向风 定义的东亚夏季风指数 $\left(20^{\circ} \mathrm{N} \sim 30^{\circ} \mathrm{N}, 110^{\circ} \mathrm{E} \sim 130^{\circ} \mathrm{E}\right.$; $\mathrm{Wu}$ 和 $\mathrm{Ni}, 1997)$ 的相关系数为 0.49 , 都通过了 $90 \%$ 的蒙 特卡洛显著性检验; 而蒙古高原降水与东亚夏季风指 数之间的相关性却非常低. 结合上文的分析可知, 东 亚夏季风的增强并不能直接导致蒙古高原降水的增 多, 而是需要通过蒙古高原上空的异常气旋才有可能 影响到蒙古高原. 此外, 蒙古高原上空的高度场异常 也是导致了蒙古高原降水与东亚夏季风出现同相位变 化的主要原因.

除了水汽因素, 动力条件对降水也起着至关重要 的作用. 为此, 我们将蒙古高原降水与 $500 \mathrm{hPa}$ 垂直速 度进行回归分析, 结果显示在蒙古高原降水增多时, 蒙古高原、中国东北和华北地区无辐散层出现了显著 的上升运动(图6). 根据垂直运动方程, 长波槽前会出 现上升运动, 槽后出现下沉运动(Holton, 2004). 由此

\section{图 $5850 \mathrm{hPa}$ 气候态高度场和蒙古高原区域平均夏季降水与 $850 \mathrm{hPa}$ 高度场的回归分析(a)以及东北亚低压指数与低层水汽 通量的回归分析(b)}

(a)中高度场单位为 $m$, 蓝色和红色实线为气候态等高线, 黑色实线和虚线分别表示正和负高度场异常, 红色虚线长方形区域为东北亚高度场 异常核心区 $\left(45^{\circ} \mathrm{N} \sim 57.5^{\circ} \mathrm{N}, 105^{\circ} \mathrm{E} \sim 125^{\circ} \mathrm{E}\right)$, 灰色阴影部分表示回归分析通过了 $90 \%$ 的显著性检验; (b) 中东北亚低压指数定义为东北亚高度场 异常核心区区域平均 $850 \mathrm{hPa}$ 高度场异常, 水汽通量单位为 $\mathrm{kg} \mathrm{m}^{-1} \mathrm{~s}^{-1}$, 蓝色箭头表示水汽通量通过了 $90 \%$ 显著性检验 


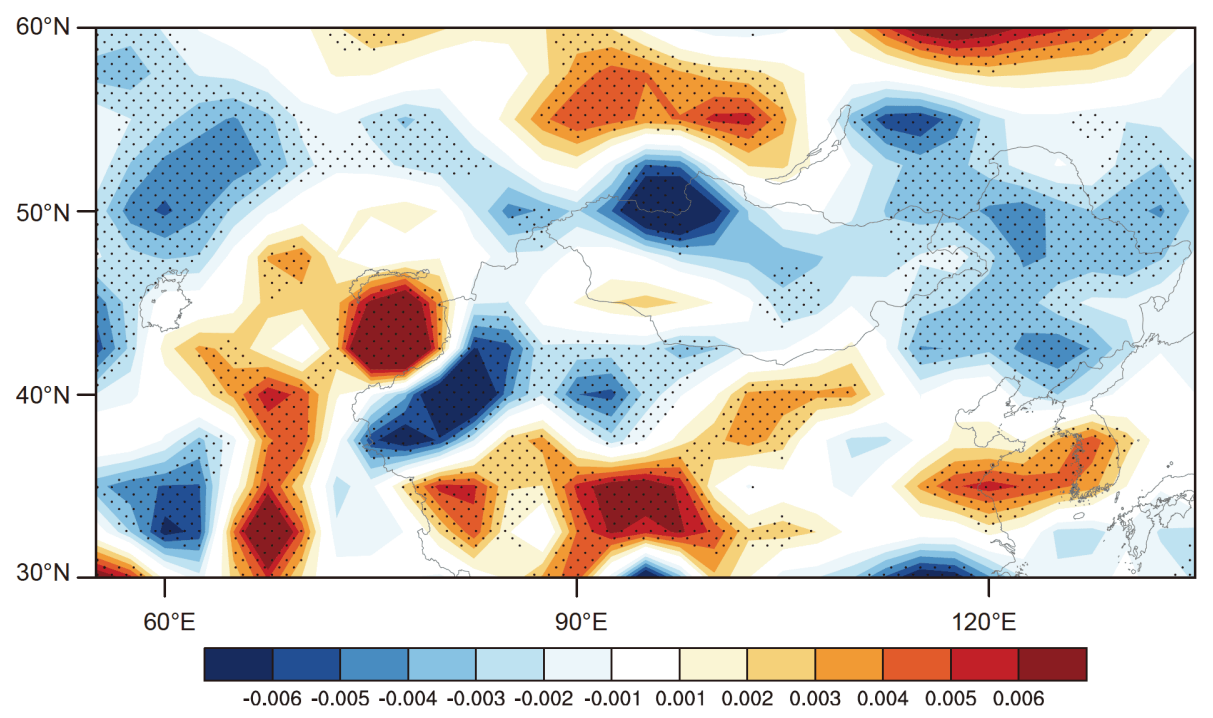

图 6 蒙古高原区域平均夏季降水与500hPa垂直速度的回归分析

垂直速度单位为 $\mathrm{Pa} \mathrm{s}^{-1}$, 黑色圆点代表回归分析通过了 $90 \%$ 的显著性检验

导致位于长波槽前的蒙古高原、中国东北和华北地区 出现显著的上升运动(图4和图6), 为降水提供必要的 动力支持.

综上所述，本文发现北大西洋和中亚地区与欧洲 和蒙古高原高度场异常反相位配置的欧亚大陆中纬度 遥相关波列是导致蒙古高原和中纬度东亚季风区夏季 降水一致性变化的关键：当北大西洋和中亚地区为高 度场正异常，而蒙古高原出现高度场负异常这种环流 配置时, 蒙古高原出现异常气旋, 将更多的西风和中 纬度季风水汽输送到蒙古高原和中纬度中亚季风区。 与此同时，由这个遥相关波列引起的蒙古高原上空的 高度场负异常可以加强东北亚低压，使得南北经向位 势高度梯度加大，从而导致东亚夏季风增强，从低纬 输送到中纬度的季风水汽增多。此外，这个遥相关波 列还可以激发蒙古高原、中国东北和华北地区的异常 上升运动. 可见, 尽管中国东北和华北地区夏季受季风 环流控制, 但是西风环流对它的影响也至关重要, 并且 中低纬之间的相互作用也使得西风环流和季风环流的 联系异常紧密，以至于受不同环流控制的蒙古高原和 中纬度东亚季风区的夏季降水出现一致性的变化.

\section{4 结论与讨论}

本文通过对1979 2016年蒙古高原夏季降水变化
进行分析, 发现在年际和年代际尺度上, 蒙古高原与中 纬度东亚季风区的夏季降水都具有一致性变化特征, 降水一致性变化区域主要为蒙古高原、中国东北和华 北地区，通过进一步对这种一致性变化降水模态的成 因进行分析，发现蒙古高原和中纬度东亚季风区异常 降水的水汽来源基本一致, 主要是西风和东亚夏季风 水汽. 如图7所示，当蒙古高原降水增多时，欧亚大陆 出现一个遥相关波列, 该波列在蒙古高原上空表现为 高度场负异常，导致该地区出现一个准正压结构的异 常气旋，能够将异常西风水汽和到达华北的季风水汽 进一步输送到蒙古高原和东北, 为这些地区降水的增 加提供必要的水汽条件. 不仅如此, 蒙古高原上空的 高度场负异常还可以加强东北亚低压，使得大陆低压 和西太平洋副热带高压之间的经向位势高度梯度加 强, 导致季风前端的地转西风加强, 将更多的低纬季风 水汽输送到华北地区，从而导致蒙古高原和中纬度东 亚季风区降水同时增加，并且西风和东亚夏季风表现 为同时增强. 此外，欧亚大陆中纬度遥相关波列还可 以激发蒙古高原、中国东北和华北的异常上升运动. 因此，异常西风和季风水汽的输送以及异常抬升运动 共同导致了主要受西风环流控制的蒙古高原和受季风 环流控制的中纬度东亚季风区降水变化特征一致.

从更大空间范围来看, 年代际尺度蒙古高原-中纬 度东亚季风区与同位于中纬度的中亚夏季降水近 40 年 


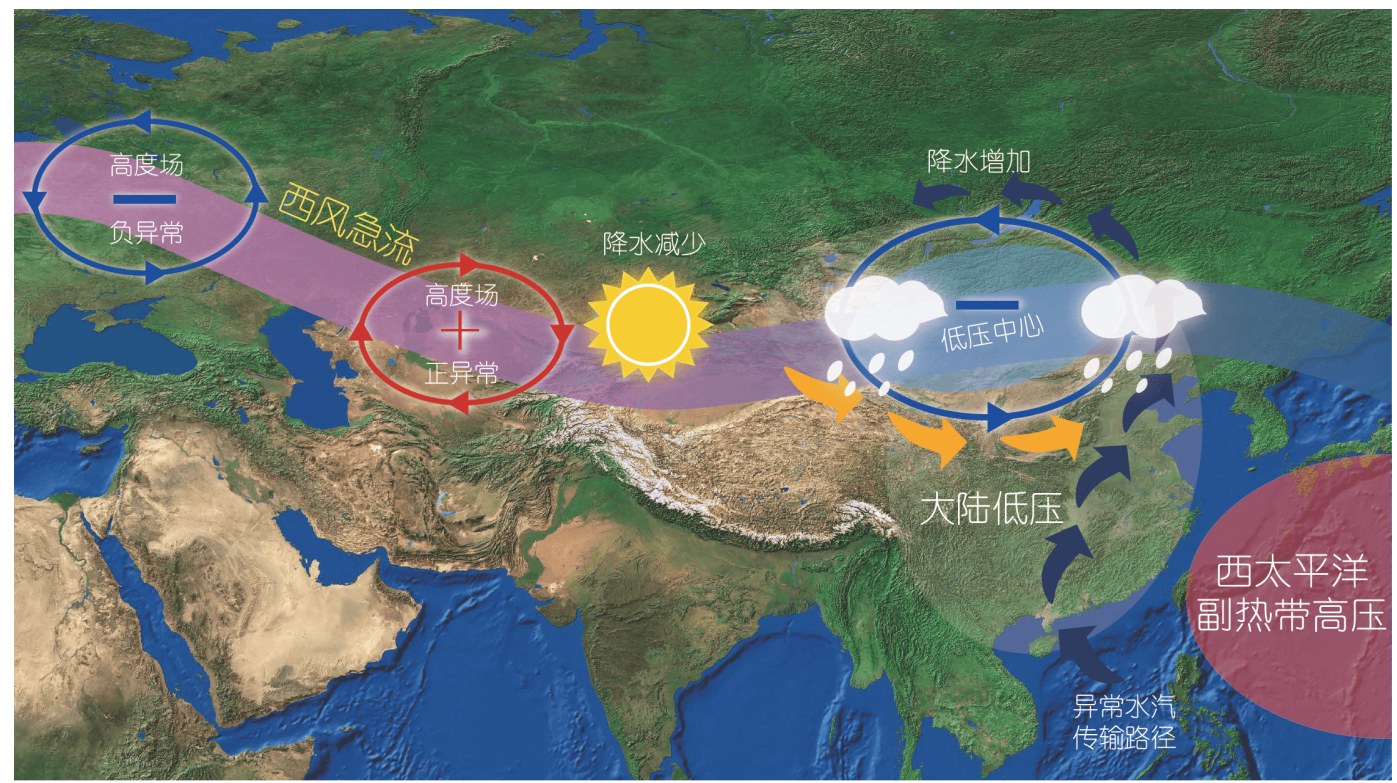

图 7 蒙古高原与中纬度东亚季风区夏季年代际降水同相位变化机制示意图

来表现为显著的反相位变化特征(图2a 2d). 尽管过去 百年中亚反相位范围与近40年相比变小(图2e)，但这 极有可能是过去百余年中亚观测资料稀缺所导致，而 非反相位模态的减弱。“西风模态”在全新世不同时间 尺度的稳定存在也表明中亚与蒙古高原-中纬度东亚 季风区降水年代际反相位模态的稳定(Chen等，2019). 事实上，蒙古高原和中亚都位于西风环流影响区．然 而，蒙古高原降水变化特征却与同处西风影响区的中 亚相反，与中纬度东亚季风区一致. 从水汽输送角度, 蒙古高原-中纬度东亚季风区降水增多时，欧亚大陆中 纬度遥相关波列在中亚上空表现为高度场正异常，蒙 古高原的异常气旋将更多的西风和季风水汽输送至蒙 古高原和中纬度东亚季风区的同时，中亚上空高度场 正异常所导致的异常反气旋也将水汽输送至中国并且 使得水汽在中亚辐散，水汽减少，不利于降水的形成 (图3和图4). 从动力抬升角度，根据垂直运动方程，欧 亚大陆遥相关波列在蒙古高原、中国东北和华北激发 异常上升运动的同时，也导致位于长波槽后的中亚东 部出现显著的下沉运动，抑制上升运动的形成(图4和 图6). 可见，蒙古高原-中纬度东亚季风区与中亚的降 水反相位变化特征主要由异常水汽输送和动力抬升运 动在蒙古高原-中纬度东亚季风区与中亚的反相位变 化导致(图7).
Chen等(2008)使用了11条包括蒙古高原的干早区 湖泊集成代用记录发现，干旱区湿度在晚全新世出现 了降低. 然而, Chen等(2016)进一步参考黄伟等(2015) 划定的“西风模态”核心区范围，重建了西风模态核心 区湿度记录，结果却显示核心区全新世以来湿度一直 在增加．根据本文蒙古高原和中纬度东亚季风区夏季 降水同相位而与中亚干旱区反相位的结果可以推测, Chen等(2008)集成的中亚干旱区代用记录极有可能混 合了东亚季风区的信号，从而导致这两个结果存在差 异. 可见, 从现代气候背景角度厘清这种气候背景的 区域异同, 对古气候研究有重要的参考价值.

本文的结果仅仅依据观测资料得到, 然而, 从更长 时间尺度的古气候角度, 气候背景存在差异时, 年际和 年代际蒙古高原与华北降水一致性变化甚至与中亚的 年代际反相位变化是否依然存在? 其空间范围和物理 机制是否存在差异? 从不同时间尺度角度，例如百年 和千年尺度，蒙古高原与华北降水一致性变化的模态 是否也存在? 这些都需要将可靠的高分辨率古气候重 建记录与数值模拟相结合，深入地探讨多时空尺度亚 洲中纬度降水变化特征及其物理机制, 为深入认识亚 洲降水时空格局提供扎实的理论依据. 本文仅仅是初 步的探讨了现代亚洲中纬度降水格局，上述相关工作 还需要逐步地开展. 


\section{参考文献}

陈婕, 黄伟, 靳立亚, 陈建徽, 陈圣乾, 陈发虎. 2018. 东亚夏季风的气 候北界指标及其年际变化研究. 中国科学: 地球科学, 48: 93-101

陈际龙, 黄荣辉. 2007. 亚澳季风各子系统气候学特征的异同研究II. 夏季风水汽输送. 大气科学, 31: 766-778

郭其蕴. 1983. 东亚夏季风强度指数及其变化的分析. 地理学报, 38 207-217

黄伟, 陈建徽, 张肖剑, Feng S, 陈发虎. 2015. 现代气候条件下降水变 化的“西风模态”空间范围及其影响因子初探. 中国科学：地球科 学, 45: 379-388

An C B, Chen F H, Barton L. 2008. Holocene environmental changes in Mongolia: A review. Glob Planet Change, 63: 283-289

An Z. 2000. The history and variability of the East Asian paleomonsoon climate. Quat Sci Rev, 19: 171-187

Chen F, Yu Z, Yang M, Ito E, Wang S, Madsen D B, Huang X, Zhao Y, Sato T, John B. Birks H, Boomer I, Chen J, An C, Wünnemann B. 2008. Holocene moisture evolution in arid central Asia and its outof-phase relationship with Asian monsoon history. Quat Sci Rev, 27: $351-364$

Chen F, Jia J, Chen J, Li G, Zhang X, Xie H, Xia D, Huang W, An C. 2016. A persistent Holocene wetting trend in arid central Asia, with wettest conditions in the late Holocene, revealed by multi-proxy analyses of loess-paleosol sequences in Xinjiang, China. Quat Sci Rev, 146: 134-146

Chen F, Chen J, Huang W, Chen S, Huang X, Jin L, Jia J, Zhang X, An C, Zhang J, Zhao Y, Yu Z, Zhang R, Liu J, Zhou A, Feng S. 2019. Westerlies Asia and monsoonal Asia: Spatiotemporal differences in climate change and possible mechanisms on decadal to sub-orbital timescales. Earth-Sci Rev, 192: 337-354

Cheng H, Wu T, Dong W. 2008. Thermal contrast between the middlelatitude Asian continent and adjacent ocean and its connection to the East Asian summer precipitation. J Clim, 21: 4992-5007

Chung Y, Kim H, Dulam J, Harris J. 2003. On heavy dustfall observed with explosive sandstorms in Chongwon-Chongju, Korea in 2002. Atmos Environ, 37: 3425-3433

Dee D P, Uppala S M, Simmons A J, Berrisford P, Poli P, Kobayashi S, Andrae U, Balmaseda M A, Balsamo G, Bauer P, Bechtold P, Beljaars A C M, van de Berg L, Bidlot J, Bormann N, Delsol C, Dragani R, Fuentes M, Geer A J, Haimberger L, Healy S B, Hersbach H, Hólm E V, Isaksen L, Kållberg P, Köhler M, Matricardi M, McNally A P, Monge-Sanz B M, Morcrette J J, Park B K, Peubey C, de Rosnay P, Tavolato C, Thépaut J N, Vitart F. 2011. The ERA-Interim reanalysis: Configuration and performance of the data assimilation system. Q J R Meteorol Soc, 137: 553-597

Duchon C E. 1979. Lanczos filtering in one and two dimensions. J Appl
Meteor, 18: 1016-1022

Fujiwara H, Fukuyama T, Shirato Y, Ohkuro T, Taniyama I, Zhang T H. 2007. Deposition of atmospheric ${ }^{137} \mathrm{Cs}$ in Japan associated with the Asian dust event of March 2002. Sci Total Environ, 384: 306315

Gunin P D, Vostokova E A, Dorofeyuk N I, Tarasov P E, Black C C. 1999. Vegetation dynamics of Mongolia. Dordrecht: Kluwer Academic. 238

Han J, Wang H. 2007. Interdecadal variability of the East Asian summer monsoon in an AGCM. Adv Atmos Sci, 24: 808-818

Harris I, Jones P D, Osborn T J, Lister D H. 2014. Updated highresolution grids of monthly climatic observations-The CRU TS3.10 Dataset. Int J Climatol, 34: 623-642

Holton J R. 2004. An Introduction to Dynamic Meteorology. 4th ed. Burlington: Elsevier Academic Press. 535

Huang R H, Liu Y, Feng T. 2013. Interdecadal change of summer precipitation over Eastern China around the late-1990s and associated circulation anomalies, internal dynamical causes. Chin Sci Bull, 58: 1339-1349

Huffman G J, Adler R F, Bolvin D T, Gu G. 2009. Improving the global precipitation record: GPCP Version 2.1. Geophys Res Lett, 36: L17808

Lee E H, Sohn B J. 2011. Recent increasing trend in dust frequency over Mongolia and Inner Mongolia regions and its association with climate and surface condition change. Atmos Environ, 45: 46114616

Li J, Cook E R, Chen F, Davi N, D'Arrigo R, Gou X, Wright W E, Fang K, Jin L, Shi J, Yang T. 2009. Summer monsoon moisture variability over China and Mongolia during the past four centuries. Geophys Res Lett, 36: L22705

Liu J, Rühland K M, Chen J, Xu Y, Chen S, Chen Q, Huang W, Xu Q, Chen F, Smol J P. 2017. Aerosol-weakened summer monsoons decrease lake fertilization on the Chinese Loess Plateau. Nat Clim Change, 7: 190-194

Lin Z, Wang B. 2016. Northern East Asian low and its impact on the interannual variation of East Asian summer rainfall. Clim Dyn, 46: 83-97

Munkhtsetseg E, Kimura R, Wang J, Shinoda M. 2007. Pasture yield response to precipitation and high temperature in Mongolia. J Arid Environ, 70: 94-110

Piao J, Chen W, Wei K, Liu Y, Graf H F, Ahn J B, Pogoreltsev A. 2017. An abrupt rainfall decrease over the Asian inland plateau region around 1999 and the possible underlying mechanism. Adv Atmos Sci, 34: 456-468

Piao J, Chen W, Zhang Q, Hu P. 2018. Comparison of moisture transport between Siberia and northeast Asia on annual and 
interannual time scales. J Clim, 31: 7645-7660

Schneider U, Becker A, Finger P, Meyer-Christoffer A, Rudolf B, Ziese

M. 2018. GPCC Full Data Monthly Product Version 2018 at $0.5^{\circ}$ :

Monthly Land-Surface Precipitation from Rain-Gauges built on GTS-based and Historical Data. Global Precipitation and Climatology Centre

Sato T, Tsujimura M, Yamanaka T, Iwasaki H, Sugimoto A, Sugita M,

Kimura F, Davaa G, Oyunbaatar D. 2007. Water sources in semiarid northeast Asia as revealed by field observations and isotope transport model. J Geophys Res, 112: D17112

Wang W, Feng Z. 2013. Holocene moisture evolution across the Mongolian Plateau and its surrounding areas: A synthesis of climatic records. Earth-Sci Rev, 122: 38-57

Wesche K, Ambarlı D, Kamp J, Török P, Treiber J, Dengler J. 2016. The Palaearctic steppe biome: A new synthesis. Biodivers Conserv, 25: $2197-2231$

Wu A, Ni Q. 1997. The influence of Tibetan Plateau on the interannual variability of Asian monsoon. Adv Atmos Sci, 14: 491-504

Xu Z Q, Fan K, Wang H J. 2015. Decadal variation of summer precipitation over China and associated atmospheric circulation after the late 1990s. J Clim, 28: 4086-4106

Yamanaka T, Tsujimura M, Oyunbaatar D, Davaa G. 2007. Isotopic variation of precipitation over eastern Mongolia and its implication for the atmospheric water cycle. J Hydrol, 333: 21-34

Zhu Y, Wang H, Zhou W, Ma J. 2011. Recent changes in the summer precipitation pattern in East China and the background circulation. Clim Dyn, 36: 1463-1473

Zhu Y, Wang T, Wang H. 2016. Relative contribution of the anthropogenic forcing and natural variability to the interdecadal shift of climate during the late 1970s and 1990s. Sci Bull, 61: 416424

Zuo Z, Yang S, Zhang R, Jiang P, Zhang L, Wang F. 2013. Long-term variations of broad-scale Asian summer monsoon circulation and possible causes. J Clim, 26: 8947-8961

(责任编委: 陈文) 